\author{
Лариса Сливка, \\ кандидат педагогічних наук, доцент кафедри \\ педагогіки початкової освіти, \\ ДВНЗ «Прикарпатський національний \\ університет імені Василя Стефаника» \\ (м. Івано-Франківськ, Україна) \\ Larysa Slyvka, \\ $\mathrm{PhD}$ in Education, Associate Professor, \\ Department of Pedagogy of Primary Education, \\ Vasyl Stefanyk Precarpathian national university \\ (Ivano-Frankivsk, Ukraine) \\ loroczka@ukr.net \\ ORCID ID 0000-0003-1865-6326
}

УдК: 371.71: 37(438)

\title{
ОСВІТА І ВИХОВАННЯ У ЗДОРОВ'ЯЗБЕРЕЖЕННІ ДІТЕЙ ТА МОЛОДІ: ЗАГАЛЬНОЄВРОПЕЙСЬКА РЕТРОСПЕКТИВА, СТАНОВЛЕННЯ НА ПОЛЬСЬКИХ ЗЕМЛЯХ
}

\begin{abstract}
Анотація. У статті схарактеризовано дидактичні аспекти оптимізації здоров'язбереження дітей та молоді Яна Амоса Коменського, висвітлено здоров'яорієнтований вимір системи «виховання джентльмена» Джона Локка, увиразнено здоров'язбережувальну педагогічну програму Жана-Жака Руссо. Репрезентовано погляди Клода Адріана Гельвеція про роль фізичного виховання у формуванні здоров'я зростаючої особистості. Представлено практичні аспекти здоров'язбереження учнів, реалізовані Йоганном Генріхом Песталоцці. Актуалізовано бачення Иогана Христофа Фридриха Гутса-Мутса щодо здоров'язбережувальної функції фізичного виховання. Анонсовано погляди Джованні Боско і Герберта Спенсера про роль фізкультурного складника у здоров'язбереженні. Представлено гуманістичні концепції освіти і виховання Еллен Кароліни Софії Кей, Вільгельма Августа Лая, Георга Кершенштейнера та Марії Монтессорі.
\end{abstract}

Ключові слова: здоров'я дітей та молоді, здоров'язбереження, освіта, фізичне виховання, шкільна гігієна, доба Просвітництва, Новий час, польські мислителі.

\section{EDUCATION IN THE CHILDREN'S AND YOUNG PEOPLE'S HEALTH SAVING: EUROPEAN RETROSPECTIV, BECOMING IN THE POLAND LANDS}

Abstract. The article presents domestic researchers, who researched the retrospective of formation of pedagogical models of health saving of growing personality : V. Bobrycka, Y. Boychuk, E. Bulych, I. Muravov, O. Vashchenko, S. Verhratski, P. Zabludovski, I. Dacenko, P. Djurynski, T. Yermakova, V. Yefimova, N. Mogaricheva, L. Jovnirenko, S, Kyrylenko, V. Kuksa, L. Sushchenko, S. Fil, O. Hudoliy, G. Malka, L. Sheremet and polish researchers L. Vynnychuk, B. Galonzka, M. Demel, T. Drabchyk, P. Mazur, E. Pyasecki and others. Summarizing the content of the intelligence of the mentioned authors showed that the most studied in the context of the topic of the article is the «ancient» period of human civilization and the Renaissance. The article describes Jan Amos Komensky's didactic aspects of optimization of health care of children and youth, highlights the health-oriented dimensiom of John Locke's gentleman's upbringing, expressed Jean-Jacques Rousseau's health-saving pedagogical program. Claude Adrian Helvetius' views on physical education as a means of shaping the health of a growing personality are represented. The article presents the Johann Henry Pestalozzi's health-saving practices. The vision of the health-saving function of physical education by Johann Christoph Friedrich Guts-Muts is updated. Giovanni Bosco and Herbert Spencer's views on physical component in health-saving activiyies announced. The article presents the humanistic concepts of education and upbringing of Ellen Carolina Sophia Kay, Wilhelm August Lai, Georg Kerschensteiner and Maria Montessori.

Keywords: children's and young people's health, health saving, education, physical education, school hygiene, Enlightenment Era, Modern Times, polish thinkers.

\section{ВСТУП}

Постановка проблеми. Історія здоров'язбережувального виховання $€$ неперервним явищем. Тому звернення до витоків цих виховних впливів зумовлено потребою з'ясування зародження педагогічних канонів, цінностей і дискурсів означеного змісту.

Аналіз наукових досліджень і публікацій. Низку узагальнень щодо історичного «шляху» людства у формуванні педагогічних моделей здоров'язбереження зростаючої особистості представлено у працях вітчизняних дослідників 
В. Бобрицької, Ю. Бойчука, О. Ващенко, С. Верхратського, П. Заблудовського, І. Даценко, П. Джуринського, Л. Жовніренко, С. Кириленко, В. Кукси, Л. Сущенко, С. Філя, О. Худолія, Г. Малки, Л. Шеремет та польських вчених Л. Винничук, Б. Ґалонзки, М. Демела, Т. Драбчика, П. Мазура, Е. П'ясецького, ін. Аналіз змісту розвідок згаданих авторів засвідчив, що найбільш вивченими у зазначеному контексті $€$ «античний» період розвитку людської цивілізації і доба Відродження.

\section{МЕТА І ЗАВДАННЯ ДОСЛІДЖЕННЯ}

Метою нашого дослідження $€$ репрезентувати низку виховних здоров'язбережувальних концепцій і практик епохи Просвітництва і Нового часу.

\section{МЕТОДИ ДОСЛІДЖЕННЯ}

Для розв'язання поставлених у статті завдань використано такі методи наукового дослідження: історикоструктурний, конструктивно-генетичний, історико-педагогічний аналіз, узагальнення, порівняння наукових джерел, системний і проблемно-цільовий аналіз філософської, науково-педагогічної літератури та ресурсів мережі Інтернет.

\section{РЕЗУЛЬТАТИ ДОСЛІДЖЕННЯ}

Теоретична і практична спадщина щодо здоров'язбереження зростаючої особистості репрезентантів античної цивілізації, «середніх» віків і культурно-філософського руху, відомого як Відродження, стала підґрунтям розроблення педагогічних аспектів розв'язання проблеми збереження, зміцнення і формування здоров'я дітей та молоді представниками наступних поколінь мислителів і дослідників. Доба Просвітництва (XVII-XVIII ст.) стала своєрідним «спадкоємцем» «відродженського» руху, представники якого анонсували просвітницькі ідеї у вибраному колі близьких їм за духом гуманістів. Своєю чергою, діяльність «просвітників» вирізнялася спробами передати свої знання якомога ширшому колу співгромадян і реалізувати це найбільш зрозумілим для загалу способом. Здоров'яорієнтований вектор знань напрацьовувався паралельно із «просвітницькими» ідеями щодо потреби змін і реформ суспільства, віри у безмежні можливості людського розуму, вірогідності побудови справедливого людського суспільства на засадах отримання наукових знань, удосконалення розумного начала людини і важливої місії у цьому освіти та виховання.

Яскравим репрезентантом «дидактично-освітнього» виміру оптимізації здоров'язбереження дітей та молоді був чеський мислитель, педагог і письменник Ян Амос Коменський (чеськ. Jan Amos Komenskэ; 1592-1670). Стратегія і тактика вченого щодо організації роботи школи були результатом творчого осмислення ним величезного пласту знань про людину та її здоров'я, репрезентованих в анатомії, фізіології, гігієні, медицині та психології, у вченнях про значення соціальних чинників і довкілля у збереженні здоров'я дітей та підлітків, про основи раціонального харчування. За Я.А. Коменським, при організації будь-яких видів шкільної роботи на «першому» місці повинні бути інтереси і здоров'я учня. Серед обов'язкових умов ефективного навчання та виховання науковець виокремлював тривале перебування учнів на свіжому повітрі, активні фізичні вправи, якісний сон, помірне харчування. Здоровий спосіб життя особистості педагог ідентифікував із «помірним способом життя» і наполягав на необхідності формування у дитини звичок «помірності» в усьому: у їжі, у питті, у сні, у праці, в іграх, у розмові, у мовчанні тощо (Коменский Я.А., 1982, с. 22, 69, 128, 323, 405). Увиразненням міркувань вченого про створення сприятливого здоров'ю освітнього середовища є, приміром, зміст праці «Закони добре організованої школи», в якій автор актуалізував необхідність дотримання гігієнічних норм при виборі місця для розташування школи та облаштуванні її приміщень (Коменский Я.А., 1991, с. 186). У школі Я.А. Коменського були спеціальні локації для прогулянок, ігор, фізичних вправ, сад з деревами і квітами, де вихованці мали змогу відпочити після уроків (Mazur P., 2014, s. 64). Після «статичних» теоретичних занять, протягом двох-трьох годин, учні видатного педагога мали змогу грати у м'яч, стріляти з лука, обертати дзиґу бичем, катати кулю на спеціальному майданчику, пересуватися на ходулях, влучати кульками у кільце, ін. Неабияку роль у формуванні здоров'язбережувальних компетентностей вихованців Я.А. Коменський відводив особистому прикладу вчителя, про що засвідчує написаний вченим «моральний кодекс педагогів», в якому, серед іншого, декларовано обов'язок учителя бути взірцем щодо тверезості, помірності, здорового і бадьорого духу, працелюбства і скромності. Крім того, вчений вважав, що серед обов'язкових компонентів професійної підготовки учителів чільне місце повинні посідати навчальні дисципліни анатомія, фізіологія та медицина (Коменский Я.А., 1991, с. 188).

Важливим джерелом поширення педагогічних ідей у добу Просвітництва стали нові жанри художньої літератури філософська повість і роман-виховання.

Серед видань означеного формату варто згадати працю «Думки про виховання» одного з основоположників емпіричної психології, англійського філософа і педагога Джона Локка (англ. John Locke; 1632-1704), в якій представлено розроблену автором систему «виховання джентльмена». Кінцеву мету такого виховання вчений вбачав у забезпеченні єдності здорового духа і здорового тіла, яку називав коротким, але повним описом щастя у цьому світі. Очевидно тому серед компонентів змісту запропонованої виховної системи Дж. Локк особливе місце відвів формуванню у вихованців уявлень про раціональний сон та «здорових» навичок харчування, а також - загартуванню і фізичній активності учнів. Популярність теоретичних ідей Дж. Локка сприяла запровадженню у навчальних закладах Англії фізичного виховання, яке реалізовувалося рухливими та спортивними іграми. Вартими уваги є думки педагога про необхідність залучення вихованців до певного ремесла (столярного, токарного, теслярства), до садівництва і сільського господарства. Дж. Локк був переконаний, що праця на свіжому повітрі, крім іншого, є корисною для здоров'я і є засобом профілактики «шкідливої бездіяльності» (Локк Д., 1987, с. 145-151). 
Систематичний виклад наповненої здоров'язбережувальним змістом програми педагогічної діяльності представлено у романі «Еміль, або про виховання» (1762) французького філософа, просвітника і письменника Жана-Жака Руссо (франц. Jean-Jacques Rousseau; 1712-1778). Пропагандист освітніх ідей вважав гігієну єдиним «корисним» складником медицини та був прихильником профілактичних засобів у плеканні здоров'я людини. «Справжніми» лікарями, на думку Ж.-Ж. Руссо, є праця, яка «загострює» апетит людини, і стриманість, яка «заважає» зловживати цим апетитом. Серед засобів зміцнення і росту тіла учнів та їхнього оздоровлення виокремлював загартування водними купелями і повітрям, фізичну та рухову активність (Руссо Ж.-Ж., 1987, с. 213-214, 226).

Про здоров'я як необхідну умову щастя людини і фізичне виховання як засіб формування та плекання здоров'я особистості писав французький літератор і філософ Клод Адріан Гельвецій (франц. Claude Adrien Helvйtius; 17151771). У праці «Про людину, їі розумові здібності та їі виховання» (1773) вчений зазначав, що фізичне виховання може зробити кожну людину сильнішою, міцнішою, здоровішою і щасливішою, такою, яка буде здатна виконувати різні функції. Одна з оригінальних ідей К. Гельвеція стосувалася будівництва на теренах шкіл «арен», на кшталт грецьких, де б вихованці могли вправлятися у боротьбі, біганні, стрибанні, плаванні, ін. Серед перших «кроків» реалізації цієї ідеї вчений називав актуалізацію позитивних інтенцій фізичного виховання в освітніх нормативноправових актах та відповідне просвітництво батьків учнів (Гельвеций К.А., 1982, с. 258-259).

Для кінця XVIII - початку XIX cт. характерні поява нових освітніх викликів, пов'язаних зокрема із розповсюдженням і демократизацією шкільництва та ідей безкоштовної освіти для широких верств населення. У цей період велися активні пошуки у новій науковій галузі - гігієні. 3 метою підготовки спеціалістів, здатних дбати про впровадження у життєдіяльність суспільства засад індивідуальної гігієни, організацію санітарних заходів серед громадськості під час епідемічних захворювань тощо, на медичних факультетах університетів відкривали спеціальності «медична поліція». Видатними європейськими гігієністами Йоганом Петером Франком (нім. Johann Peter Frank; 1745-1821), Христофом Вільгельмом Гуфеландом (нім. Christoph Wilhelm Hufeland; 1762-1836), Едмундом Парксом (англ. Edmund Alexander Parkes; 1819-1876), Мішелем Леві (франц. Michel Lйvy; 1809-1872), Максом Петтенкофером (нім. Max von Pettenkofer; 1818-1901), Карлом Флюґе (нім. Karl Georg Friedrich Wilhelm Flıgge; 1847-1923) було написано і видано низку підручників та часописів гігієнічної тематики. У лоні гігієнічної науки виокремився її складник, так звана шкільна гігієна, завданнями якої стали розроблення санітарних норм щодо будівництва освітніх закладів, медико-соціальний та гігієнічний супровід навчально-виховного середовища шкіл тощо. Ідеї гігієнічно організованого, наповненого фізкультурним виміром та орієнтованого на здоров'язбереження вихованців освітнього процесу дедалі активніше озвучувалися у педагогічній літературі та реалізовувалися практично.

Непересічною у зазначеному контексті є творча спадщина видатного швейцарського педагога Йоганна Генріха Песталоцці (нім. Johann Heinrich Pestalozzi; 1746-1827). Висвітлення теоретичних положень загальної дидактики репрезентовано у працях вченого воднораз із описом методик гігієнічного і фізичного виховання дітей та молоді. Гуманістична спрямованість діяльності педагога значною мірою визначалася його обізнаністю щодо анатомічних і фізіологічних особливостей кожного вихованця. Велике значення Й.Г. Песталоцці надавав уважному оцінюванню і визначенню динаміки стану здоров'я своїх учнів, що увиразнено у праці «Достовірні дані про стан на 1778 рік виховного закладу для бідних дітей в Нойгофі». У творах автора «Леонард і Гертруда» та «Листи пана Песталоцці пану Н.Є.Ч. про виховання бідної сільської молоді» репрезентовано низку організаційних і педагогічних умов ефективного розв'язання проблеми збереження і зміцнення здоров'я вихованців, серед яких: чистота шкільних приміщень, увага персоналу освітнього закладу до забезпечення безпеки життєдіяльності вихованців, формування в учнів навичок особистої гігієни та гігієни одягу тощо. (Песталоцци Й.Г., 1987, Леонард и Гертуда, с. 305; Песталоцци Й.Г., 1987, Письма ..., с. 311). Фізичне виховання Й.Г. Песталоцці вважав найпершим «розумним» впливом дорослих на дитину, а основою цього виховання - природне прагнення дитини до руху. Педагог відзначав роль фізичного виховання у розвитку фізичних сил зростаючої особистості та у її підготовці до праці. У розвідці «Про народну освіту та індустрію» вчений актуалізував розроблену ним систему спеціальних гімнастичних вправ - «елементарну гімнастику» - і пропонував розробити для хлопчиків і дівчат низку ігор, сприятливих комплексному розвитку фізичних задатків дитини та формуванню у неї необхідних для життєдіяльності рухів (Песталоцци Й.Г., 1987, О народном образовании и индустрии, с. 314-315).

Незаперечним внеском у справу піднесення здоров'язбережувальної функції фізичного виховання $€$ творчість німецького педагога, одного із креаторів сучасної європейської гімнастики Йогана Христофа Фридриха ГутсаМутса (нім. Johann Christoph Friedrich GutsMuths; 1759-1839). Запропоновані педагогом у фундаментальних працях «Гімнастика для молоді» (1793) та «ггри та вправи для відпочинку тіла і духа» (1795) методи фізичного виховання широко використовувалися у школах тогочасної Європи (Mazur P., 2014, s. 63).

Збереження і формування здоров'я молоді стали важливими компонентами соціально-педагогічної діяльності італійського священика Джованні Боско (італ. Giovanni Melchiorre Bosco; 1815-1888). 1845 року він організував молодіжний осередок навчання і відпочинку для хлопців - сиріт, безпритульних і з бідних родин. Дотримуючись думки про те, що спорт є незамінним засобом профілактики моральної деградації особистості, досить активно у виховній праці Дж. Боско використовував саме фізкультурний чинник. Відомими є слова священика: «Спортмайданчик мертвий - диявол живий, спортмайданчик живий - диявол мертвий». Дж. Боско був глибоко переконаний, що поряд із зміцненням м'язів, гімнастичні вправи сприяють удосконаленню і зміцненню духа, гартуванню характеру особистості і формуванню у неї моральних чеснот (Mazur P., 2014, s. 65).

Ідеями щодо необхідності формування в учнів знань про шляхи збереження здоров'я та потреби організації різноманітних форм раціонального проведення вільного часу вихованців репрезентовано у розвідці «Про розумове, моральні і фізичне виховання» англійського філософа, соціолога і педагога Герберта Спенсера (англ. Неrbert 
Spencer; 1820-1903). Звертаючи увагу на необхідність реалізації проблеми збереження і зміцнення здоров'я зростаючої особистості, вчений пропонував ввести у навчальні програми освітніх закладів гімнастику, зауважував, що їі засоби - спорт, ігри та забави - є незамінними натуральними формами рухової активності, які сприяють плеканню здоров'я (Mazur P., 2014, s. 66).

На переломі XIX і XX століть з'явилися нові концепції освіти і виховання, які впродовж досить короткого часу стали популярними, і частину яких використовували в освітній практиці. Спираючись на здобутки різних наукових галузей, у новій педагогіці увиразнилися гуманістична парадигма, індивідуальний підхід до вихованців, врахування в організації навчально-виховного процесу інтересів та здібностей учнів, використання активних методів навчання тощо.

Освіту і виховання означеного формату активно пропагувала шведська громадська діячка, письменниця і педагог Еллен Кароліна Софія Кей (швед. Ellen Karolina Sofia Key; 1849-1926). У книзі «Століття дитини» (1900) вона представила власне бачення освітнього закладу майбутнього - школи радісного життя дитини, в якому свої зусилля педагог спрямовує на здобуття вихованцями власного досвіду, стимулювання їхнього активного ставлення до життя, надання учням можливостей особистісного розвитку зручними для них засобами, підготовку кожного вихованця до тривалої впродовж життя самоосвіти; в якому представлені різноманітні локації для ручної праці; в якому у вихованні учнів тісно співпрацюють школа і родина тощо. 3 метою поширення своїх ідей 1903 року Е. Кей здійснила кілька подорожей містами Німеччини та Австрії, де читала лекції відповідної тематики (Mazur P., 2014, s. 68).

Низку критичних зауважень щодо недоліків словесних і «пасивних» методів навчання викладено у праці «Школа дії» німецького педагога Вільгельма Августа Лая (нім. Wilhelm August Lay; 1862-1926). Автор закликав до використання у навчанні методів, які сприяють формуванню творчого і самодіяльного характеру зростаючої особистості, її фізичному розвитку і збереженню здоров'я. Наголошуючи на потребі модернізації діяльності школи на засадах урахуванням вимог шкільної гігієни, освітянин пропонував створити «школу дії», основні принципи діяльності якої базувалися б на досягненнях біології, анатомії, фізіології, психології, теорії пізнання та гігієни (Лай В.А., 1982, с. 542-543).

Подібні ідеї знаходимо у розвідці «Школа майбутнього - школа праці» автора теорії громадянського виховання, німецького педагога Георга Кершенштейнера (нім. Georg Michael Kerschensteiner; 1854-1932). Вчений підкреслював потребу моделювання такого навчально-виховного процесу, який сприяв би розвитку активних рис характеру учня, його самостійності та ініціативі. Неоціненим засобом розвитку вихованців Г. Кершенштейнер вважав ручну працю, наголошував, що робота, яку учень здатен опанувати, завжди приносить йому радість і почуття щастя. Тому, на думку вченого, важливо дбати про те, щоб на теренах школи було якомога більше майданчиків - майстерень, лабораторїй, садів, музичних аудиторій, класів для малювання тощо, де б вихованці могли знайти заняття «до душі» (Кершенштейнер Г., 1982, с. 512-515).

Орієнтованістю на здоров'язбереження дітей вирізнялася система педагогічного виховання, запропонована першою італійкою, яка стала доктором медицини, освітянкою Марією Монтессорі (італ. Maria Montessori; 18701952). Важливими завданнями освіти дослідниця вважала всебічний (фізичний, духовний, культурний і соціальний) розвиток вихованців. Варто згадати, що тематика занять змістової лінії «навички практичного життя», яка реалізовувалася у «школах Монтессорі», спрямовувалася, крім іншого, на розвиток дрібної моторики, опорнорухової системи, координації рухів та ін. (Білецька Н., 2015).

Теоретична і практична спадщина представників європейської спільноти, які творили впродовж доби Просвітництва і Нового часу, стала історико-соціальними витоками і філософським підґрунтям розроблення польськими мислителями власних «національних» версій технологій освіти і виховання для здоров'я дітей та молоді.

\section{ВИСНОВКИ ТА ПЕРСПЕКТИВИ ПОДАЛЬШИХ ДОСЛІДЖЕНЬ}

Рефлексії європейської філософської, медичної, гігієнічної і педагогічної літературі доби Просвітництва і Нового часу щодо здоров'я як предмета виховання точилися навколо ідей формування тілесної досконалості та гігієнічних навичок вихованця, реалізації санітарних і безпечних норм у «фізичному» оточенні учнів. Порушувалася проблема модифікації здоров'яорієнтованого змісту професійної підготовки вчителів. На переломі XIX і XX ст. у багатьох країнах світу розгорнулися потужні суспільні гігієнічні рухи, нагромадився значний пласт фактографічного матеріалу з проблеми здоров'язбереження дітей та молоді, у навчальні програми освітніх закладів було введено дисципліну «Фізичне виховання». Значно збільшилася кількість друкованої продукції, в якій репрезентувалися теоретичні й практичні рекомендації щодо необхідності забезпечення природовідповідної та гуманістичної логіки в організації життєдіяльності школярів з урахуванням їхніх потреб, інтересів, індивідуальних особливостей та потенціалу, використання сприятливих всебічному розвитку особистості методів і засобів освіти та виховання, створення безпечних і комфортних умов перебування дітей у школі, потреби запровадження в освітніх закладах засад шкільної гігієни.

\section{СПИСОК ВИКОРИСТАНИХ ДЖЕРЕЛ}

Білецька, Н. (2015). Методика виховання Монтесcopi. Основи. URL: https://starylev.com.ua/club/article/ metodyka-vyhovannya-montessori-osnovy.

Гельвеций, К. А. (1982). О человеке, его умственных способностях и его воспитании. Коменский Я. А. и др. Избранные педагогические сочинения; в 2 т. / Под ред. А. И. Пискунова и др. М.: Педагогика, 255-265. 
Кершенштейнер, Г. (1982). Школа будущего - школа работы. Коменский Я. А. и др. Избранные педагогические сочинения; в 2 т. / Под ред. А. И. Пискунова и др. М.: Педагогика, 509 - 519.

Коменский, Я. А. (1991). Законы хорошо организованной школы. Кратохвил М. В. Жизнь Яна Амоса Коменского: книга для учителя / перевод с чешского. М.: Просвещение, 185 - 188.

Коменский, Я. А. (1982). Избранные педагогические сочинения: [в 2 т.] / [под ред. А. И. Пискунова]. М.: Педагогика, 372 с.

Лай, В.А. (1982). Школа действия. Коменский Я. А. и др. Избранные педагогические сочинения: В 2 т. / Под ред. А. И. Пискунова и др. М.: Педагогика, 534 - 558.

Локк, Д. (1987). Мысли о воспитании. Коменский Я.А., Локк Д., Руссо Ж.-Ж., Песталоцци Й. Г. Педагогическое наследие: [сборник / сост. В.М. Кларин, А.Н. Джуринский]. М.: Педагогика, 145 - 179.

Песталоцци, Й. Г. (1987). Леонард и Гертруда. Коменский Я.А., Локк Д., Руссо Ж.-Ж., Песталоцци Й.Г. Педагогическое наследие: [сборник / сост. В.М. Кларин, А.Н. Джуринский]. М.: Педагогика, 303 - 313.

Песталоцци, Й. Г. (1987). О народном образовании и индустрии. Коменский Я.А., Локк Д., Руссо Ж.-Ж., Песталоцци Й.Г. Педагогическое наследие: [сборник / сост. В.М. Кларин, А.Н. Джуринский]. М.: Педагогика, 312 - 322.

Песталоцци, Й. Г. (1987). Письма г-на Песталоцци к г-ну Н.Э.Ч. о воспитании бедной сельской молодёжи. Коменский Я.А., Локк Д., Руссо Ж.-Ж., Песталоцци Й. Г. Педагогическое наследие: [сборник / сост. В. М. Кларин, А.Н. Джуринский]. М.: Педагогика, $304-312$.

Руссо, Ж.-Ж. (1987). Эмиль, или о воспитании. Коменский Я.А., Локк Д., Руссо Ж.-Ж., Песталоцци Й.Г. Педагогическое наследие : [сборник / сост. В.М. Кларин, А.Н. Джуринский]. М.: Педагогика, 199 - 296.

Mazur, P. (2014). Zdrowie i bezpieczeństwo uczniów na przestrzeni wieków - zarys zagadnienia. Bezpieczeństwo dzieci i młodzieży. Aktualne problemy teorii i praktyki pedagogicznej / redakcja naukowa Beata Komorowska, Piotr Mazur. Chełm, 57 - 69.

\section{REFERENCES}

Bilecka, N. (2015). Metodyka vychovannia Montessori. Osnovy. URL: https://starylev.com.ua/club/article/metodyka-vyhovannya-montessori-osnovy

Gelvecij, K. A. (1982). O cheloveke, yego umstvyennych sposobnostyach i yego vospitanii. Komenskiy Y. A. i dr. Izbrannyye pedagogichyeskiye sochinyeniya: w 2 t. / pod. red. A. I. Piskynova i dr. M.: Pedagogika, $255-265$.

Kershenshtejner, G. (1982). Shkola budushchyego - shkola raboty. Komenskiy Y. A. i dr. Izbrannyye pedagogichyeskiye sochinieniya: w 2 t. / pod. red. A. I. Piskynova i dr. M.: Pedagogika, $509-519$.

Komyenskiy, Y. A. (1991). Zakony chorosho organizovannoy shkoly. Kratochvil M. V. Jyzn Yana Amosa Komyenskogo: kniga dla uchityela / perevod s cheshskogo. M.: Prosvyeshchyeniye, $185-188$.

Komyenskiy, Y. A. (1982). Izbrannyye pedagogicheskiye sochinyeniya: [v 2 t.] / [pod red. A. I. Piskunova]. M.: Pedagogika, 372 c.

Lay, V. A. (1982). Shkola dyeystviya. Komenskiy Y. A. i dr. Izbrannyye pedagogichyeskiye sochinieniya: w 2 t. / pod. red. A. I. Piskynova i dr. M.: Pedagogika, $534-558$

Lokk, D. (1987). Mysli o vospitanii. Komyenski Y. A., Lokk D., Russo J.-J., Pestalocci Y. G. Pedagogicheskoye naslyediye: [sbornik / sost. V. M. Klarin, A. N. Jurinski]. M.: Pedagogika, $145-179$.

Pestalocci, Y. G. (1987). Leonard i Gertruda. Komyenski Y. A., Lokk D., Russo J.-J., Pestalocci Y. G. Pedagogicheskoye naslyediye: [sbornik / sost. V. M. Klarin, A. N. Jurinski]. M.: Pedagogika, $303-313$.

Pestalocci, Y. G. (1987). O narodnom obrazovanii i industrii. Komyenski Y. A., Lokk D., Russo J.-J., Pestalocci Y. G. Pedagogicheskoye naslyediye: [sbornik / sost. V. M. Klarin, A. N. Jurinski]. M.: Pedagogika, $312-322$.

Pestalocci, Y. G. (1987). Pisma g-na Pestalocci k g-nu N.Ye.Ch. o vospitanii byednoy syelskoy molodyojy. Komyenski Y. A., Lokk D., Russo J.-J., Pestalocci Y. G. Pedagogicheskoye naslyediye: [sbornik / sost. V. M. Klarin, A.N.Jurinski]. M.: Pedagogika, $304-312$.

Russo, J.-J. (1987). Emil, ili o vospitanii. Komyenski Y.A., Lokk D., Russo J.-J., Pestalocci Y. G. Pedagogicheskoye naslyediye: [sbornik / sost. V. M. Klarin, A.N. Jurinski]. M.: Pedagogika, $199-296$.

Mazur, P. (2014). Zdrovie i bezpiechenstvo uczniuv na pshestsheni viekuv - zarys zagadnyenia. Bezpiechenstvo dzieci i mlodziejy. Aktualne problemy teorii i praktyki pedagogichney / redakcya naukova Beata Komorovska, Piotr Mazur. Chelm, 57 - 69. 